\title{
Penggunaan Media Kartu Pecahan untuk Meningkatkan Hasil Belajar Matematika Materi Pecahan Kelas 3 SD Ta'mirul Islam Inovatif
}

\section{Kokom Siti Komariah}

SD Ta'mirul Islam Inovatif

kom.db23@gmail.com

\section{Article History}

received 3/12/2020

\begin{abstract}
This research is about Classroom Activity Research (PTK), this research is for students of Sd Ta'mirul Islam Surakarta. The numbers of the students are 26 students consists of 12 boys and 14 girls. Tje purpose of the research is to increase the result of learning from the third grade of SD Ta'mirul Islam Surakarta by using fraction card media. The result of learning pre cycle with the standard of minimum criteria of mastery learning $(\mathrm{kkm}) 75$ is got from the average class, it is 68,6. in the first cycle the average class score is 77,5. The number who is completed the learning is 19 students or $73 \%$. In the second cycle the average class score is 81,1 . The observation data shows the result of learning is increase. The number is 23 students or $88 \%$ are completed the learning, and who is not finished the learning is about 3 students or $12 \%$. So the conclusion is the result of learning by using fraction card media can increase the score, activeness, and can motivate the students.
\end{abstract}

Keywords: outcomes learning, fraction card, learning media

\begin{abstract}
Abstrak
Penelitian ini adalah Penelitian Tindakan Kelas (PTK) yang dilaksanakan pada peserta didik SD Ta'mirul Islam Surakarta yang berjumlah 26, terdiri dari 12 laki-laki dan 14 perempuan. Penelitian ini bertujuan untuk meningkatkan hasil belajar peserta didik kelas 3 SD Ta'mirul Islam dengan menggunakan media kartu pecahan. Hasil pembelajaran Prasiklus dengan KKM 75 diperoleh rerata kelas 68,6 . Pada Siklus I nilai rerata kelas 77,5 , yang tuntas dalam belajar berjumlah 19 atau $73 \%$. Pada Siklus II hasil nilai rerata kelas adalah 81,1. Data pengamatan hasil belajar juga menunjukkan peningkatan yaitu sebanyak 23 orang atau $88 \%$ tuntas dalam belajar, dan yang belum tuntas ada 3 orang atau $12 \%$. Dengan demikian pembelajaran menggunakan media kartu pecahan dapat meningkatkan hasil belajar, keaktifan dan motivasi bagi peserta didik.
\end{abstract}

Kata kunci: hasil belajar, kartu pecahan, media pembelajaran

Social, Humanities, and Education Studies (SHEs): Conference Series https://jurnal.uns.ac.id/shes

p-ISSN 2620-9284

e-ISSN 2620-9292 


\section{PENDAHULUAN}

Peningkatan kualitas sumber daya manusia (SDM) mempunyai posisi yang strategis bagi keberhasilan dan kelanjutan pembangunan nasional. Wadah yang tepat sebagai upaya peningkatan sumber daya manusia (SDM) adalah pendidikan. Pendidikan terdiri dari berbagai jenjang, namun yang jenjang pendidikan yang paling utama dan paling dasar untuk meningkatkan kualitas sumber daya manusia (SDM) adalah pendidikan sekolah dasar (SD). Sekolah Dasar merupakan salah satu penyelenggara tingkat pendidikan yang mengembangkan potensi peserta didik pada aspek kognitif, afektif dan psikomotorik secara memuaskan guna menghadapi tuntutan pendidikan dan guna meningkatkan kualitas sumber daya manusia (SDM). Guru dalam pembelajaran menggunakan metode, pendekatan dan teknik mengajar yang relevan. Selain itu guru juga menggunakan alat peraga dan media pembelajaran sebagai penunjang dalam proses belajar mengajar. Sehingga guru dapat kreatif, aktif dan inovatif untuk menciptakan perkembangan baru di dunia pendidikan.

Salah satu ilmu dasar yang mendasari perkembangan teknologi modern adalah matematika. Untuk menguasai dan menciptakan teknologi masa depan diperlukan penguasaan matematika sejak dini. Namun pada kenyataannya matematika masih dianggap pelajaran yang sulit dan sukar dipahami oleh sebagian besar peserta didik. Hal ini senada dengan Widjajanti dan Wahyudin dalam Azizah (2016) yang mengatakan bahwa sebagian besar peserta didik menjadi malas dan kurang tertarik dalam pelajaran matematika, oleh karena itu matematika merupakan pelajaran yang sukar dan sulit, bahkan menakutkan, ditambah dengan penampilan guru matematika yang terkesan tidak bersahabat dangan peserta didik. Pengalaman awal berinteraksi dengan benda konkret ini akan membentuk dasar bagi pembelajaran selanjutnya, yaitu tahap abstrak atau tahap kedua. Pembelajaran matematika di SD pada dasarnya adalah kegiatan. Pada peserta didik SD, matematika adalah kegiatan konkret. Untuk itu,guru perlu menyiapkan strategi atau Perencanaan mengajar secara matang. Agar pembelajaran Peserta didik SD bisa menyenangkan. Pembelajaran matematika diharapkan mengembangkan potensi peserta didik, peserta didik diharapkan bisa mengkonstruksikan pemahamannya sendiri dengan guru sebagai fasilitator bukan sebagai sumber utama pembelajaran.

Media pembelajaran adalah bagian yang tidak terpisahkan dari proses belajar mengajar demi tercapainya tujuan pendidikan pada umumnya dan tujuan pembelajaran di sekolah pada khususnya (M. Basyaruddin dan Asnawir Usman, 2012). Selain itu juga media pembelajaran dapat meningkatkan motivasi belajar peserta didik dan minat peserta didik dalam mengikuti kegiatan pembelajaran. Hal ini karena peserta didik kelas III SD masih bersifat operasional konkret yaitu dalam pemahamannya masih membutuhkan bantuan dari benda-benda nyata yang dapat menjelaskan materi yang disampaikan.

Kebanyakan peserta didik Kelas III masih banyak yang mengalami kesulitan ketika mempelajari matematika. Nilai rerata pelajaran matematika lebih rendah dibandingkan dengan mata pelajaran yang lain. Hasil belajar maematika pada materi pecahan dari 26 peserta didik diperoleh rata-rata 68,6. Data dari hasil tes formatif Prasiklus hanya 6 peserta didik atau 23\% yang tuntas. Sedangkan sisanya 20 peserta didik atau $77 \%$ belum tuntas dari KKM yang ditetapkan sekolah, yaitu 75 . Banyak hal yang berpengaruh terhadap hasil belajar peserta didik, dimulai dari faktor sekolah, guru, terutama peserta didik dan guru itu sendiri. Hasil identifikasi masalah diketahui pembelajaran berlangsung monoton kurang memotivasi peserta didik dan belum menggunakan alat peraga. Dengan menggunakan media pembelajaran yang tepat, yang tidak hanya menanamkan peserta didik menghapal rumus-rumus, diharapkan akan mampu meningkatkan kualitas proses dan hasil belajar peserta didik.

Penggunaan alat peraga dalam pembelajaran matematika materi pecahan selama ini kurang maksimal, guru masih sering menggunakan metode ceramah 
sehingga peserta didik kurang aktif dalam mengikuti pembelajaran di kelas. Hal itu dibuktikan dengan interaksi guru dan peserta didik masih kurang, terlihat dari peserta didik belum aktif bertanya dalam pembelajaran. Guru merupakan faktor yang paling berpengaruh dalam meningkatkan pemahaman peserta didik akan suatu materi pembelajaran, karena guru memiliki peran untuk membimbing dan memfasilitasi peserta didik dalam mengikuti proses pembelajaran. Hal ini menjadi salah satu penyebab rendahnya hasil belajar mata pelajaran matematika tentang materi pecahan sederhana.

Rendahnya hasil belajar materi pecahan sederhana peserta didik kelas III SD Ta'mirul Islam, mendorong saya untuk melakukan penelitian. Hal ini bertujuan untuk meningkatkan pemahaman peserta didik tentang konsep pecahan sederhana pada kompetensi dasar membandingkan pecahan.

Media pembelajaran dalam proses pembelajaran matematika akan membantu memusatkan perhatian peserta didik. Media pembelajaran yang dapat diamati dan dipegang langsung ketika melakukan kegiatan belajar dapat meningkatkan minat peserta didik dalam mengikuti pembelajaran matematika. Selain itu, media pembelajaran juga dapat membantu guru dalam menyampaikan materi pembelajaran sehingga mempermudah peserta didik dalam memahami konsep materi tersebut.

Dalam upaya peningkatan kualitas pendidikan harus lebih banyak dilakukan pengajar untuk melaksanakan tugas dan tanggung jawab sebagai pendidik. Salah satunya yaitu untuk peningkatan proses pembelajaran yang penggunaan medianya secara efektif dan dapat meningkatkan kualitas hasil belajar yang baik (Sanaky, 2009). Salah satu alternatif media pembelajaran yang dapat digunakan adalah kartu pecahan. Kartu pecahan adalah media pembelajaran yang efektif untuk pembelajaran matematika kompetensi dasar membandingkan pecahan sederhana. Hal tersebut karena kartu pecahan memenuhi kriteria media pembelajaran yang baik. Kriteria tersebut antara lain: sederhana, mudah digunakan, mudah disimpan, memperlancar pembelajaran, tahan lama, sesuai dengan topik yang diajarkan, tidak menimbulkan salah tafsir dan mengarah pada satu pengertian.

\section{METODE}

Tulisan ini menggunakan jenis penelitian Penelitian Tindakan Kelas (PTK). menurut Wardhani IGAK (2016) dan Endah Norhayati (2017) mendefinisikan penelitian tindakan sebagai "systematic inquiry" yang dilakukan oleh guru, kepala sekolah, atau konselor sekolah untuk mengumpulkan informasi tentang berbagai praktik yang dilakukannya.

Iskandar (2009) dan Isman (2013) menyampaikan bahwa PTK dapat membantu seseorang terutama guru dalam mengatasai secara praktis persoalan yang dihadapi, membantu pencapaian tujuan pembelajaran. Sukayati (2008) dan Rahmat Fauzi, et al. (2011) menyampaikan bahwa Tujuan PTK adalah 1) Meningkatkan dan memperbaiki pembelajaran 2) Meningkatkan mutu pendidikan. 3) Menumbuhkembangkan budaya akademik di lingkungan sekolah.

Subjek penelitian berjumlah 26 peserta didik SD Ta'mirul Islam. Teknik pengumpulan data dengan tes, data berupa hasil belajar. Sedangkan data nontes dilakukan dengan teknik observasi. Teknik analisis data dengan teknik deskriptif komparatif, yang mendeskripsikan dan membandingkan data penelitian dengan indikator kinerja untuk menentukan keberhasilan tindakan. Teknik analisis data sesuai dengan jenis data penelitian, yaitu data kualitatif dan data kuantitatif.

Prosedur penelitian ini adalah model Siklus yang terdiri dari 4 tahap yang saling berkaitan dan berulang. Empat tahap tersebut adalah perencanaan, tindakan, pengamatan dan refleksi. Dalam setiap siklus terdiri dari 2 pertemuan. 
HASIL DAN PEMBAHASAN

Pada kegiatan pra Prasiklus menggunaka metode pembelajaran ceramah dan media papan tulis, didapat hasil ulangan matematika materi pecahan masih rendah. Rendahnya hasil belajar tersebut sesuai dengan proses pembelajaran yang pasif dan berpusat pada guru. Peserta didik masih kurang dalam merespon guru, masih senang bermain, tidak berani berpendapat dan kesulitan dalam membuat kesimpulan. Berikut ini adalah data nilai peserta didik pada saat ulangan harian matematika materi pecahan sederhana dengan kompentensi dasar membandingkan pecahan sederhana.

Tabel 1. Nilai Ulangan Peserta Didik Prasiklus

\begin{tabular}{cccl}
\hline No & Nama & Nilai & Keterangan \\
\hline 1 & AR & 65 & Belum Tuntas \\
2 & AF & 53 & Belum Tuntas \\
3 & DF & 87 & Tuntas \\
4 & DM & 85 & Tuntas \\
5 & KR & 80 & Tuntas \\
6 & LK & 50 & Belum Tuntas \\
7 & MH & 70 & Belum Tuntas \\
8 & NQ & 67 & Belum Tuntas \\
9 & SI & 77 & Tuntas \\
10 & KH & 60 & Belum Tuntas \\
11 & TFA & 85 & Tuntas \\
12 & ZFA & 63 & Belum Tuntas \\
13 & DAP & 60 & Belum Tuntas \\
14 & KAZ & 53 & Belum Tuntas \\
15 & ASA & 57 & Belum Tuntas \\
16 & AR & 60 & Belum Tuntas \\
17 & AK & 63 & Belum Tuntas \\
18 & KFP & 65 & Belum Tuntas \\
19 & KS & 67 & Belum Tuntas \\
20 & KRA & 83 & Tuntas \\
21 & MI & 70 & Belum Tuntas \\
22 & NY & 95 & Tuntas \\
23 & RR & 83 & Tuntas \\
24 & SY & 60 & Belum Tuntas \\
25 & RN & 53 & Belum Tuntas \\
26 & SP & 73 & Belum Tuntas \\
\hline & & & \\
\hline
\end{tabular}

Hasil pembelajaran Prasiklus dengan KKM 75 diperoleh rerata kelas 68,6, dengan ketuntasan belajar sebesar 30,8\% atau 8 peserta didik dari keseluruhan 26 peserta didik. Hasil belajar termasuk rendah karena nilai rata-rata tidak memenuhi KKM sebesar 75 dan ketuntasan minimal sebesar $75 \%$.

Pada Pembelajaran siklus I pertemuan I materi yang disampaikan kepada peserta didik adalah matematika mengenal pecahan sederhana, mengklasifikasikan pecahan berdasarkan penyebutnya dan sedikit menjelaskan tentang membandingkan pecahan sederhana dengan menggunakan kartu pecahan. Sedangkan pada pertemuan II pada mata pelajaran matematika menjelaskan tentang membandingkan 
pecahan sederhana secara detail dengan menggunakan media kartu pecahan yang dilakukan melalui sebuah permainan. Pada kegiatan inti guru menjelaskan tentang konsep membandingkan pecahan sederhana dengan menggunakan media kartu pecahan. Setelah peserta didik memahami konsep membandingkan pecahan sederhana kemudian guru meminta peserta didik untuk melakukan permainan kartu pecahan. Pada saat melakukan permainan kartu pecahan peserta didik dan guru berdiskusi tentang hasil jawaban dari permainan kartu pecahan. Oleh karena itu tercipta suasana yang kondusif dan terjadi interaksi aktif antara guru dengan peserta didik. Berikut ini tabel hasil belajar matematika peserta didik materi pecahan sederhana kompetensi dasar membandingkan pecahan sederhana pada siklus I.

Tabel 2. Nilai Ulangan Peserta Didik Siklus I

\begin{tabular}{cccl}
\hline No & Nama & Nilai & Keterangan \\
\hline 1 & AR & 77 & Tuntas \\
2 & AF & 65 & Belum Tuntas \\
3 & DF & 87 & Tuntas \\
4 & DM & 83 & Tuntas \\
5 & KR & 90 & Tuntas \\
6 & LK & 75 & Tuntas \\
7 & MH & 80 & Tuntas \\
8 & NQ & 77 & Tuntas \\
9 & SI & 80 & Tuntas \\
10 & KH & 67 & Belum Tuntas \\
11 & TFA & 87 & Tuntas \\
12 & ZFA & 75 & Tuntas \\
13 & DAP & 77 & Tuntas \\
14 & KAZ & 60 & Belum Tuntas \\
15 & ASA & 67 & Belum Tuntas \\
16 & AR & 73 & Belum Tuntas \\
17 & AK & 77 & Tuntas \\
18 & KFP & 77 & Tuntas \\
19 & KS & 80 & Tuntas \\
20 & KRA & 87 & Tuntas \\
21 & MI & 80 & Tuntas \\
22 & NY & 95 & Tuntas \\
23 & RR & 85 & Tuntas \\
24 & SY & 70 & Belum Tuntas \\
25 & RN & 65 & Belum Tuntas \\
26 & SP & 80 & Tuntas \\
\hline & & & \\
\hline
\end{tabular}

Pada pembelajaran di siklus I, peserta didik merespon dengan cukup baik terlihat dari rerata hasil belajar naik menjadi $77,5 \%$, yang tuntas dalam pembelajaran berjumlah 19 atau $73 \%$.

Dari hasil tindakan siklus I yang telah teurai seperti di atas maka dapat disimpulkan bahwa hasil belajar matematika materi pecahan sederhana kompetensi dasar membandingkan pecahan sederhana telah mengalami peningkatan. Tetapi 
tindakan pada siklus I belum memenuhi nilai target yang ingin dicapai. Maka penelitian harus dilanjutkan pada tindakan siklus ke -2.

Pada pembelajaran di siklus II, pertemuan 1 guru menjelaskan materi pecahan sederhana media kartu pecahan. Sedangkan pada pertemuan Ke-2 guru menfokuskan pada penerapan permainan kartu pecahan menggunakan media kartu pecahan. Guru sudah menyiapkan media pembelajaran yang akan digunakan pada saat proses pembelajaran. Pada kegiatan inti media kartu pecahan digunakan untuk menjelaskan tentang klasifikasi pecahan sederhana dan membandingkan pecahan sederhana. Guru menjelaskan aturan permainan kartu pecahan secara jelas dan disertai dengan memberikan contoh dalam melakukan permainan kartu pecahan. Peserta didik diberi kesempatan untuk bertanya jika mengalami kebingungan. Setelah peserta didik memahami konsep membandingkan pecahan dalam permainan kartu pecahan sederhana kemudian guru meminta peserta didik untuk melakukan permainan kartu pecahan. Pada saat melakukan permainan kartu pecahan peserta didik dan guru berdiskusi tentang hasil jawaban dari permainan kartu pecahan. Oleh karena itu tercipta suasana yang kondusif dan terjadi interaksi aktif antara guru dengan peserta didik. Berikut ini tabel hasil belajar matematika peserta didik materi pecahan sederhana kompetensi dasar membandingkan pecahan sederhana pada siklus II.

Tabel 3. Nilai Ulangan Peserta Didik Siklus II

\begin{tabular}{cccl}
\hline No & Nama & Nilai & Keterangan \\
\hline 1 & AR & 83 & Tuntas \\
2 & AF & 77 & Tuntas \\
3 & DF & 87 & Tuntas \\
4 & DM & 85 & Tuntas \\
5 & KR & 93 & Tuntas \\
6 & LK & 80 & Tuntas \\
7 & MH & 80 & Tuntas \\
8 & NQ & 80 & Tuntas \\
9 & SI & 83 & Tuntas \\
10 & KH & 75 & Tuntas \\
11 & TFA & 87 & Tuntas \\
12 & ZFA & 77 & Tuntas \\
13 & DAP & 80 & Tuntas \\
14 & KAZ & 60 & Belum Tuntas \\
15 & ASA & 77 & Tuntas \\
16 & AR & 73 & Belum Tuntas \\
17 & AK & 80 & Tuntas \\
18 & KFP & 77 & Tuntas \\
19 & KS & 85 & Tuntas \\
20 & KRA & 85 & Tuntas \\
21 & MI & 83 & Tuntas \\
22 & NY & 100 & Tuntas \\
23 & RR & 87 & Tuntas \\
24 & SY & 80 & Tuntas \\
25 & RN & 70 & Belum Tuntas \\
26 & SP & 85 & Tuntas \\
\hline & & & \\
\hline
\end{tabular}


Berdasarkan tabel di atas pembelajaran pada siklus II, peserta didik merespon dengan baik terlihat dari rerata hasil belajar naik menjadi 81,1 , dan yang tuntas melebihi KKM berjumlah 23 orang atau $88 \%$.

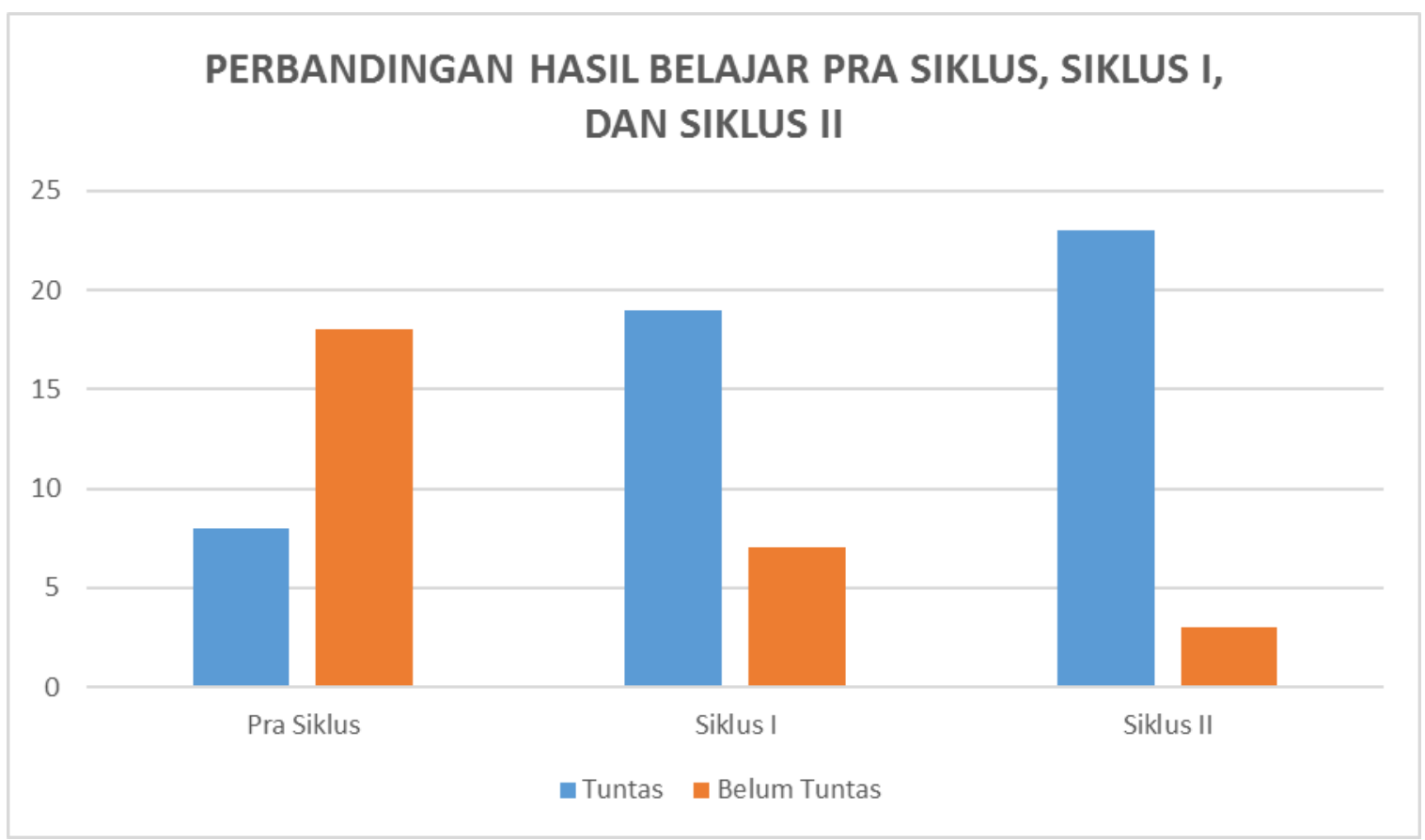

Gambar 1. Perbandingan Hasil Belajar Pra Siklus, Siklus I, dan Siklus II

Berdasarkan gambar di atas, terlihat bahwa pembelajaran matematika materi pecahan sederhana kompetensi dasar membandingkan pecahan sederhana dengan menggunakan media kartu pecahan mampu meningkatkan hasil belajar peserta didik. Peserta didik lebih mudah memahami materi membandingkan pecahan sederhana melalui permainan menggunakan media kartu pecahan. Pembelajaran lebih menarik dan menyenangkan karena peserta didik dapat belajar sambil bermain. Pembelajaran lebih bermakna karena peserta didik peserta didik secara tidak langsung belajar membandingkan pecahan sederhana secara berkelompok melalui sebuah permainan sehingga semua peserta didik aktif mengikuti pembelajaran. Selain itu dalam pembelajaran ini melatih peserta didik untuk memiliki keterampilan berpikir maupun keterampilan sosial seperti keterampilan membandingkan pecahan sederhana secara cepat, bekerja sama, dan mampu memberikan apresiasi kepada peserta didik yang lain.

Hal tersebut sesuai dengan pendapat Sudjana \&Rivai (Azhar Arsyad, 2011: 24) mengenai manfaat media pembelajaran. Manfaat tersebut antara lain Bahan pembelajaran akan lebih jelas maknanya, sehingga dapat lebih dipahami oleh peserta didik dan memungkinkannya menguasai dan mencapai tujuan pembelajaran. Media kartu pecahan bermanfaat untuk memberikan pemahaman peserta didik mengenai materi membandingkan pecahan. Penelitian inipun memberikan hasil yang cukup optimal terhadap hasil belajar peserta didik. Hasil belajar matematika peserta didik kelas III SD Ta'mirul Islam meningkat setelah dilaksanakan pembelajaran matematika menggunakan media kartu pecahan yang belum pernah dilaksanakan sebelumnya.

Pemahaman peserta didik terbentuk dari pengalaman langsung peserta didik dalam bermain kartu pecahan sehingga mempermudah dalam pengerjaan operasi 
hitung pecahan. Dengan bermain kartu pecahan peserta didik dapat menghafal dan mempercepat dalam proses berhitung pecahan. Hal tersebut sejalan dengan pendapat Darhim (2001: 314) yang menyatakan bahwa kartu pecahan juga digunakan untuk menghafal fakta dasar penjumlahan, pengurangan, perkalian dan pembagian serta digunakan untuk menghafal bangun-bangun geometri.

Melalui media kartu pecahan diperoleh temuan-temuan dalam penelitian yaitu: peserta didik berinteraksi dengan temannya, peserta didik lebih mudah memahami konsep pecahan, peserta didik lebih aktif dalam pembelajaran karena pembelajaran yang menyenangkan yaitu belajar sambil bermain.

Respon peserta didik terhadap pembelajaran matematika dengan menggunakan media kartu pecahan ini sangat baik, terlihat dari kenaikan antusiasme peserta didik dan keterlibatan peserta didik dalam mengikuti proses pembelajaran. Data yang telah dideskripsikan di atas, merupakan hasil dari implikasi tindakan yang telah dilaksanakan, karena lebih dari $75 \%$ dari jumlah peserta didik tuntas KKM, maka penelitian ini diakhiri pada siklus II.

\section{SIMPULAN}

Berdasarkan hasil penelitian dan pembahasan maka dapat disimpulkan bahwa pembelajaran matematika materi pecahan dengan menggunakan media kartu pecahan pada peserta didik kelas III SD Ta'mirul Islam Inovatif dapat meningkatkan hasil belajar. Peningkatan tersebut disebabkan karena media kartu pecahan digunakan guru sebagai alat bantu pada saat mengenalkan pecahan sederhana dan pada saat membandingkan pecahan sederhana. Pada saat membandingkan pecahan sederhana media kartu pecahan digunakan melalui sebuah permainan kartu pecahan. Guru dalam menjelaskan aturan permainan sangat jelas dan disertai contoh pelaksanaan permainannya sehingga peserta didik dapat melakukan permainan kartu pecahan sesuai dengan aturan permainannya.

\section{DAFTAR PUSTAKA}

Azhar Arsyad (2011). Media Pembelajaran. Jakarta: PT Rajagrafindo Persada.

Azizah, S. 2016. Pengembangan media pembelajaran matematika berbasis Muvizu di kelas 2 Sekolah Dasar. JKPM, 1, 180-192.

Iskandar. (2009). Penelitian Tindakan Kelas. Ciputat: Gaung Persada Press.

Lenterak (2011). Pembelajaran Matematika di SD. Diakses dari

http://lenterakecil.com/pembelajaran-matematika-di-sekolah-dasar/

M. Basyaruddin dan Asnawir Usman, Media Pembelajaran (Jakarta: Ciputat Pers, 2012). HIm 2-3

Nugraheni, D. (2012). Penggunaan Media Kartu Pecahan Untuk Meningkatkan Hasil Belajar Matematika Konsep Pecahan. Jurnal Pendidikan Dasar. https://eprints.uns.ac.id/14145/1/454-1229-1-PB.pdf

Sanaky, Media Pembelajaran (Yogyakarta: Safiria Insania, 2009). HIm 1-2

Wardani, IGAK. 2014. Penelitian Tindakan Kelas. Tangerang Selatan: Universitas Terbuka. 